International Journal Of Mechanical Engineering And Information Technology

An Official Publication of IGM Publication

\title{
Leaf Protein Juice Extraction - Review
}

Authors

Janet $A^{1}$, Bharathikanna $\mathbf{R}^{2}$, Chanakyan $\mathbf{C}^{3}$, Ramadurai $\mathrm{K}^{4}$

Department of Mechanical Engineering, Parisutham Institute of Technology and Science (PITS), Thanjavur - 613006, India

Email- janetmchem@gmail.com, bharathikanna89@gmail.com,chanmech89@gmail.com, ramdurai.mech@gmail.com

\begin{abstract}
The rate of malnutrition in the developing countries is increasing as a result of increasing population, poverty, and lack of awareness on appropriate nutrition. Leaf protein in spite of its observed similarities with animal protein, is the least tapped of all protein sources. This study presents the review for importance and extraction of protein juice from a highly proteinous leaf Moringa oleifera. It has many medicinal uses of its very wide vital antioxidants, antibiotics and nutrients include vitamin and minerals. This mini - review elaborates the importance and extraction of protein juice from Moringa oleifera leaf

Keywords- Moringa oleifera, leaf, extraction, protein and antibiotics
\end{abstract}

\section{INTRODUCTION}

Moringa oleifera is one of the widely distributed and naturalised species of a monogenetic family Moringaceae ${ }^{[1]}$ which includes 13 species of trees and shrubs distributed in sub-Himalayan ranges of India, Sri Lanka, Africa and Arabia ${ }^{[2]}$. The tree ranges in height from 5 to $10 \mathrm{~m}{ }^{[3]}$ and is found wild and cultivated throughout the plains especially in hedges and in house yards.

Proteins are nitrogen-containing organic compounds, which are essential constituents of all living cells. They often occur in foods in physical or chemical combination with carbohydrates or lipids. Protein has been extracted from leaves of more than a hundred different species of temperate tropical plants ${ }^{[3]}$.

Leaves are potentially the most abundant source of edible protein, which has helped to prevent malnutrition in African societies. The protein content in leaves is said to be as high as that found in soybeans or milk, and is considered an appropriate supplement to animal protein. The extracts are also used as traditional medicine, popularly called agbo (a herbal concoction mixed with water) and agunmu (a liquid extracted from powder or milled dried leaf) among the Yoruba in Nigeria ${ }^{[2]}$.

The extraction of protein from leaf process is accomplished by squeezing for tissue disintegration ${ }^{[2]}$. In most developing countries, the extraction of leaf protein is still based on traditional procedures, involving squeezing or rubbing the leaves by hand to obtain the juice. These traditional methods are unhygienic, tedious and time consuming ${ }^{[3,4]}$. This study a preliminary work aims to design and fabricate an easy-to operate, affordable and effective machine that can extract leaf juice from which the leaf protein can be obtained by sedimentation, settling or centrifugation.

\section{CHEMICAL CONSTITUENTS OF MORINGA OLEIFERA}

The chemical constituents of the methanolic extract of Moringa oleifera leaves and seeds were investigated using Gas chromatography-mass spectrometry. The result shows that the leaf extract has more chemical constituents than seeds. These relatively diverse chemical constituents may be responsible for the medicinal properties of Moringa oleifera leaves ${ }^{[15]}$. Table 1 shows the chemical constituents of Moringa oleifera Leaf. 
Table 1: Chemical Constituents of Moringa oleifera Leaf

\begin{tabular}{|l|l|}
\hline \multicolumn{2}{|l|}{ Methanolic Extract Leaf extract of Moringa oleifera } \\
\hline 9-octadecenoic acid & $20.89 \%$ \\
\hline L-(+) -ascorbic acid- 2, 6dihexa decanoate & $19.66 \%$ \\
\hline 14-methyl-8-hexadecenal & $8.11 \%$ \\
\hline 4-hydroxyl-4-methyl-2-pentanone & $7.01 \%$ \\
\hline 3-ethyl-2, 4-dimethyl-pentane & $6.14 \%$ \\
\hline Phytol & $4.24 \%$ \\
\hline octadecamethyl-cyclononasiloxane & $1.23 \%$ \\
\hline 1, 2-benzene dicarboxylic acid & $2.46 \%$ \\
\hline 3, 4-epoxy-ethanone comprising & $1.78 \%$ \\
\hline N-(-1-methyl ethyllidene)-benzeneethanamine & $1.54 \%$ \\
\hline 4, 8, 12, 16-tetramethylheptadecan-4-olide & $2.77 \%$ \\
\hline 3-5-bis (1, 1-dimethylethyl)-phenol & $2.55 \%$ \\
\hline 1-hexadecanol & $1.23 \%$ \\
\hline 3, 7, 11, 15-tetramethyl-2 hexadecene-1-ol & $1.17 \%$ \\
\hline Hexadecanoic acid & $2.03 \%$ \\
\hline 1, 2, 3-propanetriyl ester-9octadecenoic acid & $1.23 \%$ \\
\hline
\end{tabular}

\section{LITERATURE SURVEY}

Moringa oleifera has many applications in all fields especially in medicinal and agricultural field. The table 2 shows the applications of Moringa oleifera in the agricultural field. An amount of $20 \mathrm{~g}$ of young moringa leaves was mixed with $675 \mathrm{ml}$ of 80 $\%$ ethanol as suggested by (Makker and Becker, 1996). An amount of $25 \mathrm{ml}$ (application rate) of the solution was applied per plant in the greenhouse. From the result, Moringa leaf extract increases growth and yields of tomatoes ${ }^{[4]}$.

The effect of Moringa oleifera leaf extract with water as a emulsifier at various concentrations increase the morphological and physiological characteristics of cassava, and the efficacy of $\mathrm{M}$. oleifera leaf extract in controlling zonocerus variegatus infestation on cassava ${ }^{[10]}$.
Table 2: Application of Moringa oleifera in crop growth

\begin{tabular}{|c|c|c|}
\hline Crop & Experimental Methods & Ref., \\
\hline \multirow[t]{3}{*}{ Tomato } & $\begin{array}{l}\text { Five treatments: Only water was added } \\
\text { (M0),Ethanol } 80 \% \text { was added (ME), } \\
\text { Moringa extract applied once at } 2 \text { weeks } \\
\text { from emergence (M1), Moringa extract } \\
\text { applied at } 2 \text { and } 4 \text { weeks from emergence } \\
\text { (M2) and Moringa extract applied every } 2 \\
\text { weeks to maturity, starting from two weeks } \\
\text { from germination (M3). }\end{array}$ & \multirow[t]{3}{*}{ [4] } \\
\hline & Result & \\
\hline & $\begin{array}{l}\text { Moringa leaf extract increases growth and } \\
\text { yields of tomatoes. The study recommends } \\
\text { the application of extract at M3. }\end{array}$ & \\
\hline \multirow{5}{*}{ Cassava } & Experimental Methods & \multirow{5}{*}{ [10] } \\
\hline & $\begin{array}{l}\text { The spraying duration: } 8 \text { weeks between } \\
\text { April and June at the onset of regular } \\
\text { rainfall. }\end{array}$ & \\
\hline & Best combination & \\
\hline & $\begin{array}{l}\text { Dimethoate plus cypermethrin and } \\
\text { M.oleifera leaf extract }\end{array}$ & \\
\hline & $\begin{array}{l}\text { Enhanced the morphological growth (stem } \\
\text { height and number of leaves) of the plants } \\
\text { treated with dimethoate plus cypermethrin }\end{array}$ & \\
\hline
\end{tabular}

The leaves of the Moringa oleifera tree have been reported to demonstrate antioxidant activity due to its high amount of polyphones. Moringa oleifera extracts of both mature and tender leaves exhibit strong antioxidant activity against free radicals, prevent oxidative damage to major bimolecular, and give significant protection against oxidative damage. The table 3 shows the applications of Moringa oleifera in Medicinal field [8]. 
Table 3: Application of Moringa oleifera in Medicinal field

\begin{tabular}{|l|l|l|}
\hline $\begin{array}{l}\text { Form of Moringa } \\
\text { Leaf }\end{array}$ & Ref., \\
\hline $\begin{array}{l}\text { Moringa oleifera } \\
\text { tablets }\end{array}$ & $\begin{array}{l}\text { Moringa powder with 3 binders- } \\
\text { Maize Starch, Gelatin and Micro- } \\
\text { crystalline Cellulose (MCC); Best } \\
\text { binder: Gelatin }\end{array}$ & [1] \\
\hline $\begin{array}{l}\text { Soluble Extract } \\
\text { from Moringa } \\
\text { oleifera }\end{array}$ & $\begin{array}{l}\text { Greater cytotoxicity for tumor cells } \\
\text { \& an ideal anticancer therapeutic } \\
\text { candidate to cancer cells }\end{array}$ & [6] \\
\hline $\begin{array}{l}\text { Antioxidant and } \\
\text { anticancer } \\
\text { activities } \\
\begin{array}{l}\text { Moringa oleifera } \\
\text { leaves of }\end{array}\end{array}$ & $\begin{array}{l}\text { M. oleifera dichloromethane } \\
\text { extract shows high antioxidant } \\
\text { activity, potent cancer cell } \\
\text { antiproliferation, induction of } \\
\text { quinone reductase [7] }\end{array}$ & \\
\hline $\begin{array}{l}\text { Moringa oleifera } \\
\text { leaf extracts }\end{array}$ & $\begin{array}{l}\text { Water soluble MOL extract may be } \\
\text { a novel and promising natural } \\
\text { anticancer drug candidate. }\end{array}$ & [20] \\
\hline
\end{tabular}

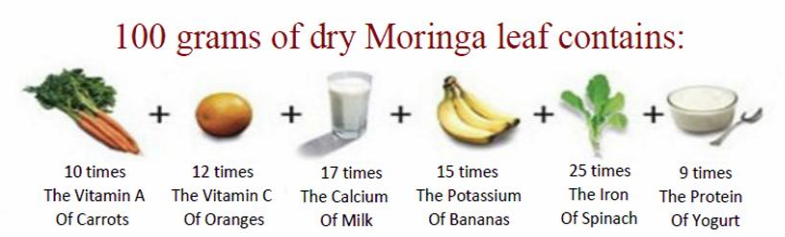

Fig. 1 Nutritional content in Moringa oleifera

Leaves are also rich in copper, manganese, zinc, selenium, and magnesium, folates, vitamin-B6 (pyridoxine), thiamin (vitamin B-1), riboflavin, pantothenic acid, and niacin. It contains $0 \%$ cholesterol ${ }^{[8]}$. It gives following health benefits:

Very helpful in management of Cardiac diseases. It contains $0 \%$ cholesterol and also beneficial for patients suffering from Hypertention.

Taking leaves regularly as a part of diet reduces chances of cancer to $80 \%$. It is also recommended as a diet of Cancer patients for healthy and quick healing.

Rich in Beta-carotene and Vitamin A, it improves Eye vision and also prevent Ageing Macular Degeneration.

It should be included in diet chart of Diabetics as beneficial in managing Sugar level.

Soup prepared from leaves is helpful in treating Menstrual cramps.

Cooked leaves if taken daily for 3 weeks removes or flushes out all the toxins from the body. It also improves immunity.

Leaf paste gently fried in castor oil can be applied over inflammations and swellings.

Rich in Calcium, very good to improve bone density. To improve bone health of kids, about 1 teaspoon of leaf juice should be mixed with milk and given twice daily.

Pregnant ladies should be given cooked leaves especially in last trimester for easy delivery.It also reduces post delivery complication and increases milk secretion in lactating women.

\section{CONCLUSIONS}

Moringa oleifera has many medicinal and agricultural applications. This study is preliminary work to fabricate a family-sized machine capable of extracting leaf juice with a maximum efficiency in commercial scale. Its ability to be motorized or powered manually makes it suitable for the developing countries.

\section{REFERENCES}

1. J. Muazu and Z. A. Suleiman, "Design, Formulation and Tableting Properties of Aqueous Leaf Extract of Moringa oleifera”, British Journal of Pharmaceutical Research, 4(19), 2261-2272, 2014

2. A.O. Raji1 and A.F. Olofin, "Design and Development of Leaf Protein Juice Extraction Machine", Journal of Industrial Research and Technology, 3(1), 69-77, 2011

3. Dr. Martin L. Price, "The Moringa tree", Echo technical note, 2007

4. Mvumi Culver, Tagwira Fanuel and Albert Z. Chiteka, "Effect of Moringa Extract on Growth and Yield of Tomato", Greener Journal of Agricultural Sciences, Vol. 2 (5), pp. 207-211, September 2012

5. Zakaria, Veni Hadju, Suryani As'ad and Burhanuddin Bahar, "The Effect of Moringa Leaf Extract in Breastfeeding Mothers against Anemia Status and Breast Milk Iron Content", International Journal of Sciences: 
Basic \&Applied Research,24(1),321-329, 15

6. Il Lae Jung, "Soluble Extract from Moringa oleifera Leaves with a New Anticancer Activity", Plos One, 9(4), 2014

7. Suphachai Charoensin, "Antioxidant and anticancer activities of Moringa oleifera leaves", Journal of Medicinal Plant Research, 8(7), 318-325, February, 2014

8. Ahmad Faizal Abdull Razis, Muhammad Din Ibrahim and Saie Brindha Kntayya, "Health Benefits of Moringa oleifera", Asian Pacific Journal Cancer Prevention, 15, 85718576, 2014

9. Majambu Mbikay, "Therapeutic Potential of Moringa oleifera Leaves in Chronic Hyperglycemia and Dyslipidemia: A Review", March 2012

10. Uchenna Mabel Ndubuaku, Theophilus Chinyere Nkasiobi Ndubuaku, Emmanuel Ike and Peter Ikemefuna Ezeaku, "Effects of Moringa oleifera leaf extract on morphological and physiological growth of cassava and its efficacy in controlling Zonocerus variegates", African Journal of Biotechnology, 14(32), 2494-2500, Aug 15

11. Isitua $\mathrm{CC}$ and Ibeh IN, "Toxicological Assessment of Aqueous Extract of Moringa Oleifera and Caulis Bambusae Leaves in Rabbits", Journal of Clinical Toxicology, 8(12), 2013

12. MS Auwal, AN Tijjani, MA Sadiq, S Saka, IA Mairiga, A Shuaibu, E Adawaren \& IA Gulani, "Antibacterial and haematological activity of Moringa oleifera aqueous seed extract in Wistar albino rats", Sokoto Journal of Veterinary Sciences, 11(1) 28-37, June 13

13. Olufunmilayo E. Adejumo, Adelodun L. Kolapo1, Akintomiwa O. Folarin, "Moringa oleifera Lam. (Moringaceae) grown in Nigeria: In vitro antisickling activity on deoxygenated erythrocyte cells", Journal of Pharmacy and Bioallied Sciences, 4(2), 118122, April-June 12

14. Aberra Melesse, Kefyalew Berihun,
"Chemical and mineral compositions of pods of Moringa stenopetala and Moringa oleifera cultivated in the lowland of Gamogofa Zone", J Environ Occup Science, 2(1), 33-38, 2013

15. P. M. Aja, N. Nwachukwu, U. A. Ibiam, I. O. Igwenyi, C. E. Offor, U. O. Orji, "chemical constituents of moringa oleifera leaves and seeds from abakaliki, nigeria", American journal of phytomedicine and clinical therapeutics, 2(3), 2014

16. Aye P.A and Adegun M. K, "Chemical Composition and some functional properties of Moringa, Leucaena and Gliricidia leaf meals" Agriculture and Biology Journal of North America, 4(1), 71-77, 2013

17. Aberra Melesse, "Comparative assessment on chemical compositions and feeding values of leaves of Moringa stenopetala and Moringa oleifera using in vitro gas production method", Ethiop .J. Appl. Sci. Technol.,2(2),31 - 41, 2011

18. Suaib Luqman, Suchita Srivastava, Ritesh Kumar, Anil KumarMaurya and Debabrata Chanda, "Experimental Assessment of Moringa oleifera Leaf and Fruit for Its Antistress, Antioxidant, and Scavenging Potential Using In Vitro and In Vivo Assays", Evidence-Based Complementary and Alternative Medicine, 1-12,2012

19. Tatiana Marrufo, Filomena Nazzaro, Emilia Mancini, Florinda Fratianni, Raffaele Coppola, Laura De Martino, Adelaide Bela Agostinho and Vincenzo De Feo, "Chemical Composition and Biological Activity of the Essential Oil from Leaves of Moringa oleifera Lam. Cultivated in Mozambique",Molecules, 18, 10989-11000, 13

20. Il lae jung, Ju hye lee and Se chan kang, “A potential oral anticancer drug candidate, Moringa oleifera leaf extract, induces the apoptosis of human hepatocellular carcinoma cells", Oncology Letters 10: 1597-1604, 2015. 